\title{
Study on the Effect of a Magnetic Field on $\mathrm{Pb}(\mathrm{II})$ Removal Using Modified Chitosan
}

\author{
Lihong Duan ${ }^{1 *}$, Siyuan Guo ${ }^{2 *}$, Jinqing Yang ${ }^{3}$ \\ ${ }^{1}$ Institute of Polymer Science, Sun Yat-sen University, Guangzhou, China \\ ${ }^{2}$ Light Industry \& Chemical Engineering Research Institute, South China University of Technology, Guangzhou, China \\ ${ }^{3}$ Guangdong Jiangmen Supervision Testing Institute of Quality \& Metrology, Jiangmen, China \\ Email: "maria.duan@gmail.com, ${ }^{*} 1$ fsyguo@scut.edu.cn
}

Received September 13, 2011; revised October 25, 2011; accepted November 6, 2011

\begin{abstract}
This work examined the removal of $\mathrm{Pb}$ (II) using a chitosan derivative (SB, synthesized from benzaldehyde) assisted by a magnetic field. The adsorption capacity for $\mathrm{Pb}(\mathrm{II})$ was investigated. It was found that 1 ) the $\mathrm{pH}$ and concentration of the ion solution, as well as exposure time and strength of magnetic field, affected the degree of adsorption; and 2) studies of the adsorption isotherms and kinetics of ions onto SB revealed that SB showed enhanced adsorption capacity towards $\mathrm{Pb}(\mathrm{II})$ ions in a magnetic field compared with magnetically untreated samples. The Langmuir and Freundlich isotherm were applied to describe the experimental adsorption, and the maximum adsorption capacity of $\mathrm{SB}$ for $\mathrm{Pb}(\mathrm{II})$ was $2.5040 \mathrm{mg} / \mathrm{g}$, when assisted by a magnetic field of $480 \mathrm{kA} / \mathrm{m}$.
\end{abstract}

Keywords: Magnetic Field; Chitosan; Pb(II); Removal

\section{Introduction}

Lead, an element belonging to non-degradable environmental pollutants, is widely distributed in nature. Lead ions and soluble lead salts are toxic and can cause harm on human health and plant growth. It can poison the nervous and blood system, cause convulsions, neurological retardation and anemia, affect child development in particular. Molecular mechanism indicates that the free state $\mathrm{Pb}(\mathrm{II})$ is toxic form, if a stable complex of the ligand can form, the concentration of free state $\mathrm{Pb}$ (II) in the human body will reduce the free state, thereby decrease the toxicity of lead on human [1].

Traditional methods for eliminating dissolved heavy metal ions include oxidation-reduction, chemical precipitation, filtration, ion exchange, electrochemical treatment, application of membrane separation and evaporation recovery. However, these processes have considerable disadvantages including incomplete metal elimination, high reagent or energy consumption, expensive equipment and monitoring system requirements and the generation of toxic sludge or other waste products that require disposal [2-5].

In this paper, a magnetic field was applied to strengthen the adsorption of $\mathrm{Pb}$ (II) ions by the adsorbent. It has been demonstrated in recent years that magnetic fields influence the physicochemical properties of water and

*Corresponding authors. aqueous solutions and suspensions [6-24]. Different hypotheses for the influence of magnetic fields on water and aqueous solutions have been extensively studied [2527]. For example, Colic and Morse [25] indicated that electromagnetic fields exerted their effects through a perturbation of the gas/liquid interface and that these effects disappeared after the system was degassed. Furthermore, Madsen [27] investigated the influence of a magnetic field on the precipitation of some inorganic salts.

Chitosan (CS) is a basic polysaccharides in which the $-\mathrm{NH}_{2}$ groups can form $-\mathrm{NH}^{3+}$ under acidic conditions. In addition, these $-\mathrm{NH}_{2}$ groups cannot entirely take part in the coordination of metal ions, limiting its adsorption capabilities and being disadvantageous for regeneration. Recently, there has been a growing interest in the chemical modification of CS to improve its water solubility and strengthen its adsorption capabilities [28-32]. For example, the $-\mathrm{NH}_{2}$ groups of $\mathrm{CS}$ can react with aldehydes or ketones to form imines (Schiff base). It was reported that chitosan Schiff base (SB) could have excellent chelation ability with heavy metal ions [33].

The purpose of this study was to investigate the adsorption behavior of $\mathrm{Pb}(\mathrm{II})$ on $\mathrm{SB}$ in a magnetic field. The influence of experimental conditions, such as exposure time, strength of magnetic field and the $\mathrm{pH}$ and concentration of $\mathrm{Pb}(\mathrm{II})$ ion solution, on the adsorption were studied. This information might be useful for further application in the treatment of waste effluents. 


\section{Experimental Procedure}

\subsection{Materials and Apparatus}

Schiff base prepared by the reaction of the $-\mathrm{NH}_{2}$ groups of CS and aldehydes of benzaldehyde (SB [34]); acetic acid and other chemicals used were analytical reagent.

The setup for generating the magnetic field, shown in Figure 1 and Table 1, was provided by the Light Industry and Chemical Engineering Research Institute at the South China University of Technology.

\subsection{Measurement of $\mathbf{P b}(\mathrm{II})$ Ions}

A stock solution $(1000 \mathrm{mg} / \mathrm{L})$ of $\mathrm{Pb}(\mathrm{II})$ ions was prepared from ultra-pure $\mathrm{Pb}\left(\mathrm{NO}_{3}\right)_{2}$. The stock solution was then diluted to give standard solutions of appropriate concentrations. The $\mathrm{pH}$ of the solutions was adjusted with $\mathrm{HNO}_{3}$ and citrate-sodium sulfite reducing solution. Then, the reaction medium was extracted with chloroform and measured using a spectrophotometer (Shimadzu UV2102PC) at $510 \mathrm{~nm}$ with diphenylhydantoin as the complexing agent.

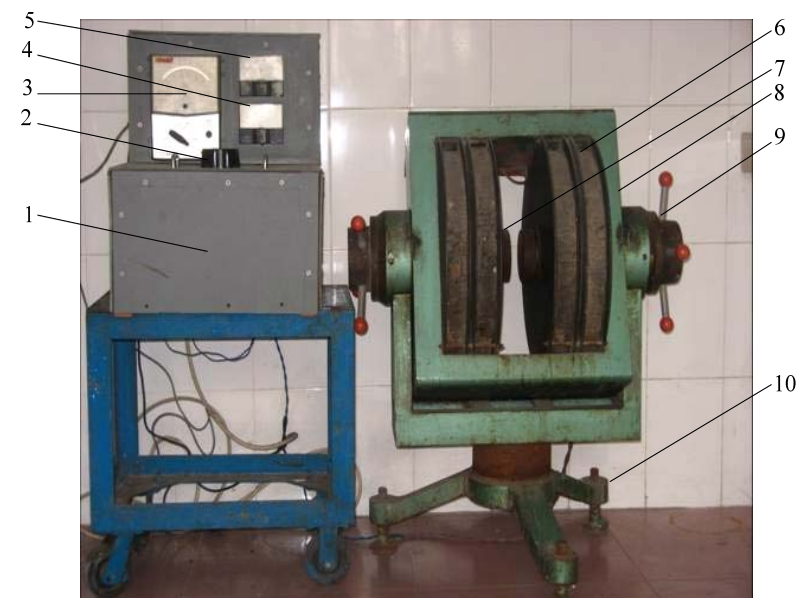

Figure 1. Adjusted magnetic field equipment. 1. Voltage transformer; 2. Regulator; 3 . Device for recording the strength of the field; 4. Ammeter; 5. Voltmeter; 6. Coil; 7. Iron core; 8. Shell; 9. Handlebar; 10. Stand.

Table 1. The main performance parameters of the magnetic field.

\begin{tabular}{lc}
\hline Main property & parameter \\
\hline Total number of turns of excitation coil & $3200 \mathrm{turns}$ \\
Total resistance of coil & $8.8 \Omega$ \\
Maximum safe magnetic current & $12.5 \mathrm{~A}$ \\
Diameter of iron core & $100 \mathrm{~mm}$ \\
Transversal surface area of magnetic pole & $78.5 \mathrm{~cm}^{2}$ \\
Space of magnetic pole & $0 \mathrm{~cm}-10 \mathrm{~cm}$ \\
Consumed power & $1.4 \mathrm{~kW}$ \\
Total weight & $440 \mathrm{Kg}$ \\
\hline
\end{tabular}

All these batch tests were conducted in $100 \mathrm{ml}$ stoppered flasks in a water bath kept at $298 \mathrm{~K}$. The agitation rate was held constant at $120 \mathrm{rpm}$.

\subsection{Adsorption Experiments}

All adsorption tests, including kinetics, isotherms and magnetic field treatment, were performed as batch experiments with duplicates. Adsorption kinetics was generated with a fixed absorbent mass and constant conditions while the adsorption of $\mathrm{Pb}(\mathrm{II})$ ions for different times was investigated. The $\mathrm{pH}$ of the metal solution in these tests was adjusted to 4 . In addition, when the adsorptions were observed in a magnetic field, the magnetic field strength was fixed at $400 \mathrm{kA} / \mathrm{m}$.

Adsorption isotherms are typically generated either with a fixed absorbent mass and varying initial $\mathrm{Pb}$ (II) ion concentration $\left(\mathrm{C}_{0}\right)$ or with varying absorbent mass and a fixed $\mathrm{C}_{0}$ level. The latter approach was used in this study. At least nine samples of $10 \mathrm{ml}$ each with different $\mathrm{Pb}$ (II) ion concentrations ranging from $5 \mathrm{mg} / \mathrm{L}$ to $30 \mathrm{mg} / \mathrm{L}$ were placed in $50 \mathrm{ml}$ conical bottles with $0.100 \mathrm{~g}$ of absorbent. The initial $\mathrm{Pb}(\mathrm{II})$ ion solutions were prepared by serial dilution of standard $1000 \mathrm{mg} / \mathrm{L}$ stock solutions.

When the effect of magnetic field treatment was studied, the magnetic field strength was varied from 160 $\mathrm{kA} / \mathrm{m}$ to $800 \mathrm{kA} / \mathrm{m}$. Meanwhile, the $\mathrm{pH}$ of the solution and the exposure time were fixed at $4 \mathrm{~min}$ and $30 \mathrm{~min}$, respectively.

\section{Results and Discussion}

Adsorption kinetics and adsorption isotherms play important roles in research on the adsorption capacity of an absorbent. Therefore, the exposure time and $\mathrm{pH}$ of metal solutions were studied in this report. Meanwhile, the effect of field strength and concentration of $\mathrm{Pb}$ (II) solution on the adsorption was also investigated. Finally, adsorption isotherms were also assessed.

\subsection{Effect of Exposure Time}

The adsorption kinetics curves of CS and SB untreated by magnetic field are shown in Figure 2 . The exposure time varied in the range of $0 \mathrm{~h}-180 \mathrm{~h}$, and the initial metal concentration was fixed at $30 \mathrm{mg} / \mathrm{L}$. According to Figure 2, the trend in adsorption quantities and adsorption rates over time was similar for CS and SB. Specifically, adsorption increased with increased exposure time but then remained almost constant after a certain value, eventually achieving equilibrium. The time to equilibrium was $120 \mathrm{~min}$ for CS and approximately $60 \mathrm{~min}$ for $\mathrm{SB}$. This phenomenon indicated that the adsorption rate of SB was higher than that of CS. It also could be seen that the adsorption quantity and adsorption rate of SB were higher than those of CS at any given time period. The ad- 
sorption quantity and adsorption rate of SB corresponded to at least $0.8907 \mathrm{mg} \mathrm{Pb}(\mathrm{II}) / \mathrm{g} \mathrm{SB}$ and $29.68 \%$ for $\mathrm{Pb}(\mathrm{II})$.

Figure 3 shows the adsorption kinetics curves of $\mathrm{CS}$ and $\mathrm{SB}$ in a magnetic field of $400 \mathrm{kA} / \mathrm{m}$. As can be seen, the trend was similar to the adsorption kinetics curves without magnetic field treatment. However, the periods required for adsorption equilibrium of $\mathrm{CS}$ and $\mathrm{SB}$ were both shorter (i.e., the equilibrium periods of CS and SB were $90 \mathrm{~min}$ and $30 \mathrm{~min}$, respectively). Comparing Figures 2 and 3, the adsorption quantity and adsorption rate of SB assisted by a magnetic field of $400 \mathrm{kA} / \mathrm{m}$ were at least $0.1003 \mathrm{mg} \mathrm{Pb}(\mathrm{II}) / \mathrm{g} \mathrm{SB}$ and $3.34 \%$ higher than that of SB without assistance of magnetic field at any given time point for $\mathrm{Pb}(\mathrm{II})$. Furthermore, the adsorption quantity and adsorption rate of SB were at least $0.6555 \mathrm{mg}$ $\mathrm{Pb}$ (II)/g SB and $21.85 \%$ more than those of CS at any corresponding adsorption period in the magnetic field of $400 \mathrm{kA} / \mathrm{m}$. Therefore, the adsorption capabilities of CS and $\mathrm{SB}$ were enhanced in the presence of a magnetic field.

\subsection{Effect of Magnetic Field Strength}

The effect of magnetic field strength on adsorption is shown in Figure 4. In light of the data presented in Figure 4 , the adsorption capability of $\mathrm{SB}$ in a magnetic field was enhanced in the magnetic field strength range of 160 $\mathrm{kA} / \mathrm{m}-800 \mathrm{kA} / \mathrm{m}$ after $30 \mathrm{~min}$. Furthermore, from 160 to $480 \mathrm{kA} / \mathrm{m}$, the adsorption quantity and adsorption rate increased dramatically. However, the change became much less outside of this field strength range. Taking into account energy conservation, the magnetic field strength of $480 \mathrm{kA} / \mathrm{m}$ was recommended for further adsorption enhancement applications.

\subsection{Effect of $P H$}

The $\mathrm{pH}$ of the metal ion solution is an important parameter in the adsorption process as a whole and on the adsorption capacity of SB in particular. Figure 5 shows the effect of $\mathrm{pH}$ on the adsorption capacity of $\mathrm{SB}$ for $\mathrm{Pb}(\mathrm{II})$ after exposure in a $480 \mathrm{kA} / \mathrm{m}$ magnetic field for $45 \mathrm{~min}$. It can be seen that the amount of $\mathrm{Pb}$ (II) adsorbed by $\mathrm{SB}$ slowly increased when the $\mathrm{pH}$ of the metal solution increased from 1 to 5 . The maximum adsorptions of $\mathrm{Pb}$ (II) ions on $\mathrm{SB}$ were found at $\mathrm{pH} 4.0$ in a $480 \mathrm{kA} / \mathrm{m}$ magnetic field.

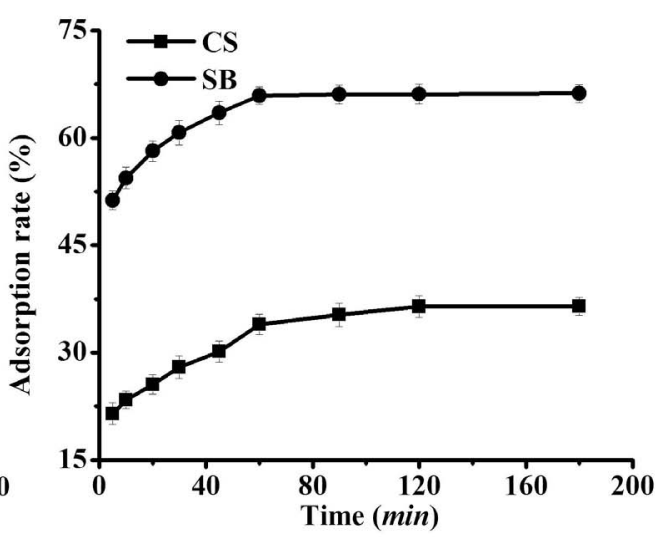

Figure 2. Effect of exposure time on adsorption of $\mathrm{Pb}(\mathrm{II})$ on CS and SB (Metal concentration: $30 \mathrm{mg} / \mathrm{L}$; Dose: $0.0100 \mathrm{~g} / \mathrm{ml}$; pH 7.4).
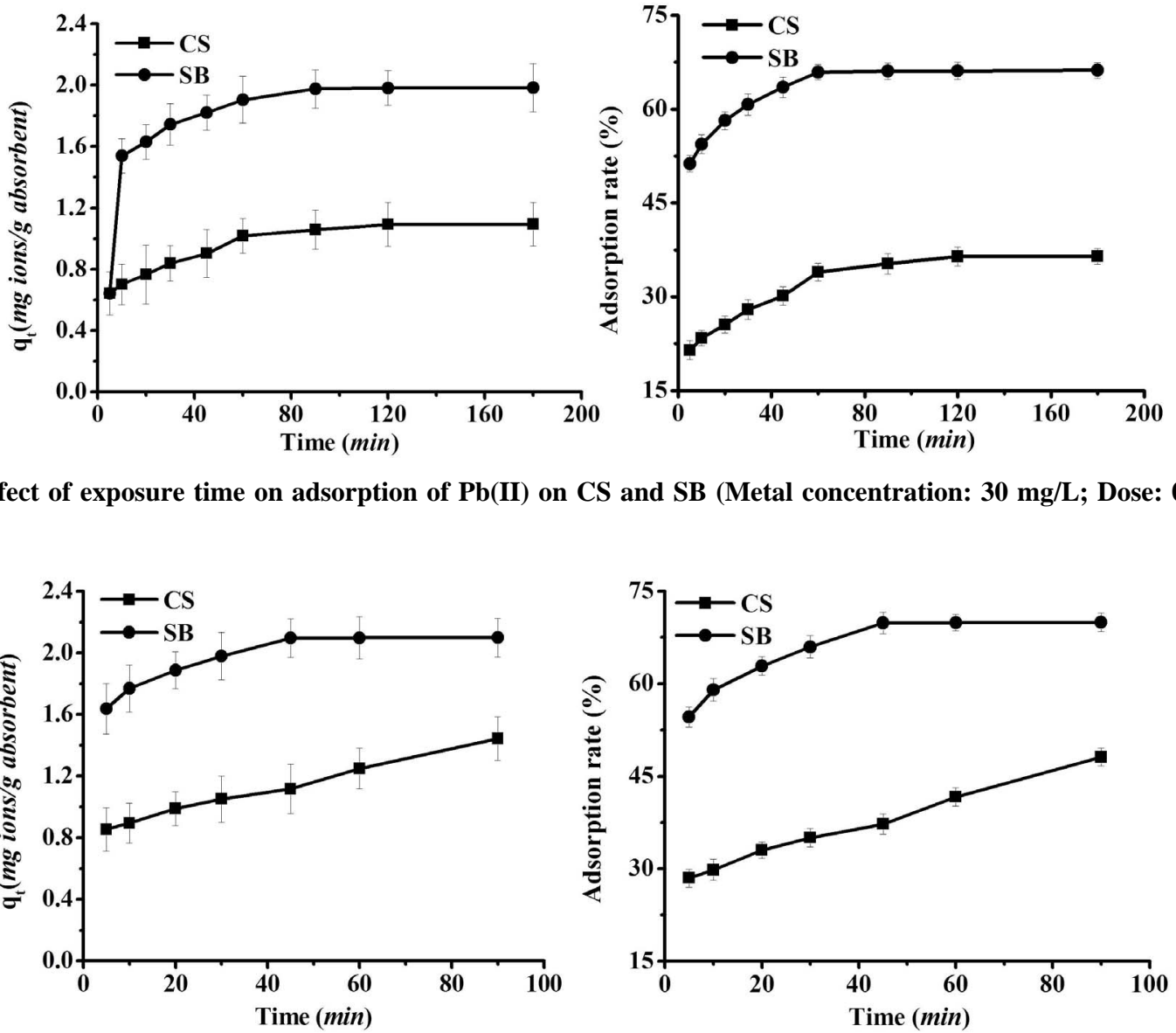

Figure 3. Effect of exposure time on adsorption of $\mathrm{Pb}(\mathrm{II})$ onto $\mathrm{CS}$ and $\mathrm{SB}$ in a magnetic field (Metal concentration: $30 \mathrm{mg} / \mathrm{L}$; Dose: $0.0100 \mathrm{~g} / \mathrm{ml}$; pH 7.4; Strength of magnetic field: $400 \mathrm{kA} / \mathrm{m}$ ). 

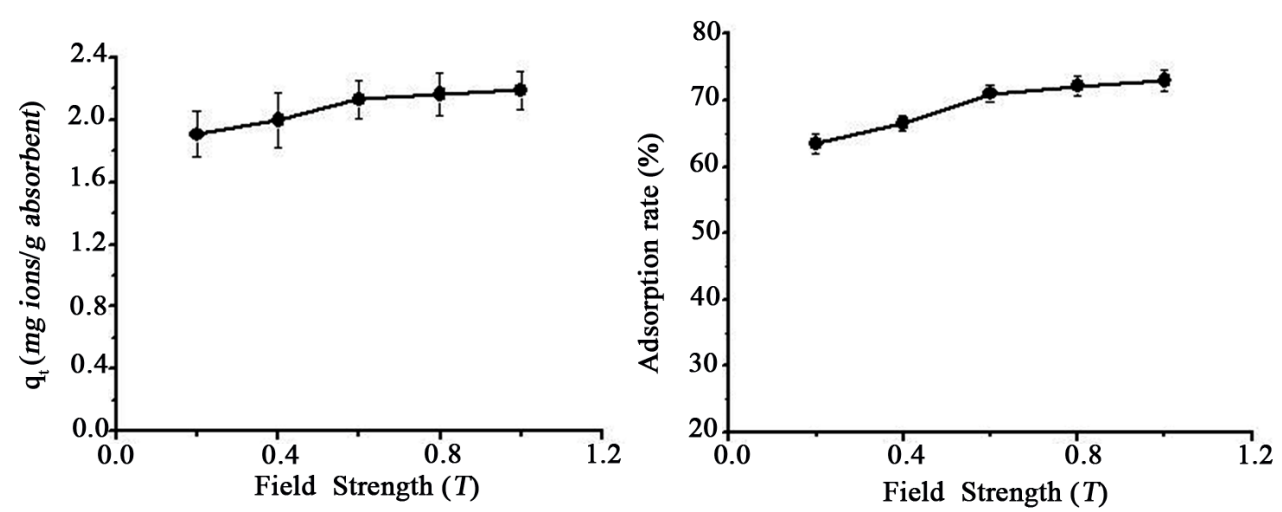

Figure 4. Effect of field strength on adsorption of $\mathrm{Pb}(\mathrm{II})$ onto $\mathrm{SB}$ in a magnetic field (Metal concentration: $30 \mathrm{mg} / \mathrm{L}$; Dose: $0.0100 \mathrm{~g} / \mathrm{ml}$; pH 7.4; Exposure time: $45 \mathrm{~min})$.
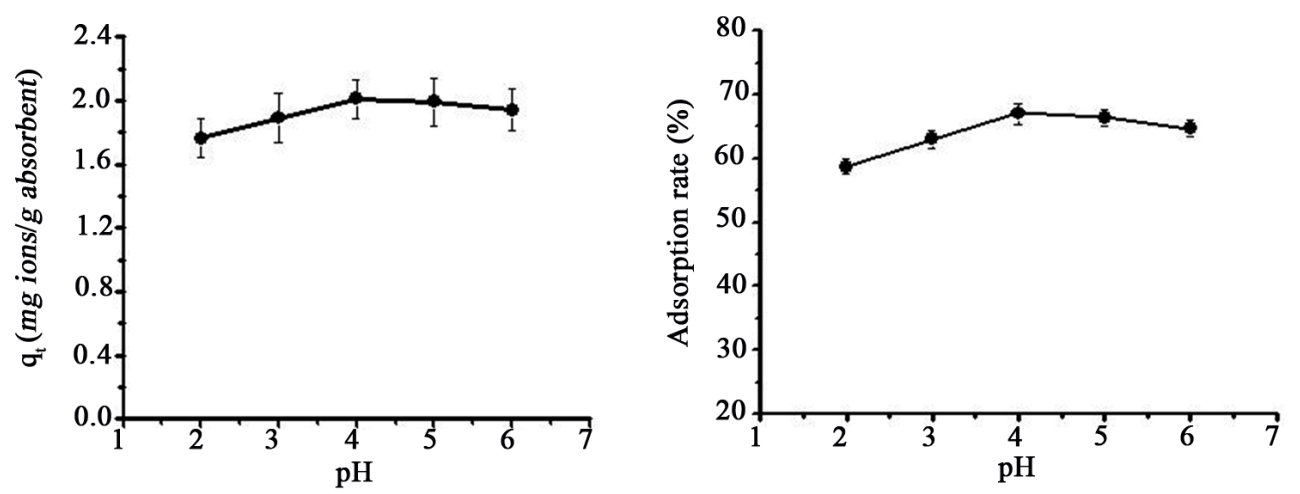

Figure 5. Effect of $\mathrm{pH}$ on adsorption of $\mathrm{Pb}(\mathrm{II})$ onto $\mathrm{SB}$ in a magnetic field (Metal concentration: $30 \mathrm{mg} / \mathrm{L}$; Dose: $0.0100 \mathrm{~g} / \mathrm{ml}$; Exposure time: $45 \mathrm{~min}$; Strength of magnetic field: $480 \mathrm{kA} / \mathrm{m}$ ).

\subsection{Adsorption Isotherms}

To investigate the adsorption mechanism, the kinetics data obtained were analyzed using the Langmuir equation (Equation (1)) and the Freundlich equation (Equation (2)).

$$
\begin{aligned}
& \mathrm{q}_{\mathrm{eq}}=\frac{\mathrm{Q}^{0} \mathrm{bC}_{\mathrm{eq}}}{1+\mathrm{bC}_{\mathrm{eq}}} \\
& \operatorname{lgq}_{\mathrm{eq}}=\lg \mathrm{K}+\frac{1}{\mathrm{n}} \lg C_{\mathrm{eq}}
\end{aligned}
$$

where $\mathrm{Q}^{0}$ is the maximum amount of metal ion per unit weight of cell to form a complete monolayer on the surface bound at high $\mathrm{C}_{\mathrm{eq}}(\mathrm{mg} / \mathrm{g})$, and $\mathrm{b}$ is a constant representing the affinity of the binding sites. $\mathrm{Q}^{0}$ stands for a practical limiting adsorption capacity when the surface is fully covered with metal ions and assists in the compareson of adsorption performance, particularly in cases where the sorbents do not reach their full saturation. Values of $\mathrm{Q}^{0}(\mathrm{mg} / \mathrm{g}), \mathrm{b}(\mathrm{L} / \mathrm{mg})$, and $\mathrm{K}$, and $1 / \mathrm{n}$ were calculated from the linear plot of $1 / \mathrm{q}_{\mathrm{eq}} \mathrm{Vs} 1 / \mathrm{C}_{\mathrm{eq}}$, the intercept of linear regression, and the plot of $\operatorname{lgq}_{\mathrm{eq}}-\operatorname{lgK} \mathrm{vs} \lg \mathrm{C}_{\mathrm{eq}}$, respectively. The metal ion adsorption experiments were carried out at different initial ion concentrations ranging from $5 \mathrm{mg} / \mathrm{L}$ to $30 \mathrm{mg} / \mathrm{L}$ at the optimum $\mathrm{pH}$ of 4 under agitation at $130 \mathrm{rpm}$. In order to develop an equation that could accurately describe the experimental results and could be used for design purposes, analysis of isotherm data was important $[2,35]$. In addition, adsorption isotherms can be used to represent how a solute interacts with an adsorbent and to optimize the use of an adsorbent.

Figure 6 displays the Langmuir and Freundlich mode$1 \mathrm{~s}$, respectively, of $\mathrm{Pb}(\mathrm{II})$ adsorption onto $\mathrm{SB}$. The correlation coefficient and linear regression values are summarized in Table 2. The data indicated that the Langmuir and Freundlich models were useful for describing the experimental data.

\subsection{The Effect of Initial Concentration of Metal Ions}

During the adsorption process of a solute from a solution onto a solid surface, there is a dynamic equilibrium between the solute adsorbed on the solid surface and the solute remaining in solution. Figure 7 reveals that the adsorption capacity of $\mathrm{SB}$ for $\mathrm{Pb}(\mathrm{II})$ ions increased with increasing metal concentration. The maximum adsorption capacity of $2.5040 \mathrm{mg} \mathrm{Pb}(\mathrm{II}) / \mathrm{g}$ SB was reached at 40 $\mathrm{mg} / \mathrm{L}$ metal ion solution concentrations. 
(a) Langmuir

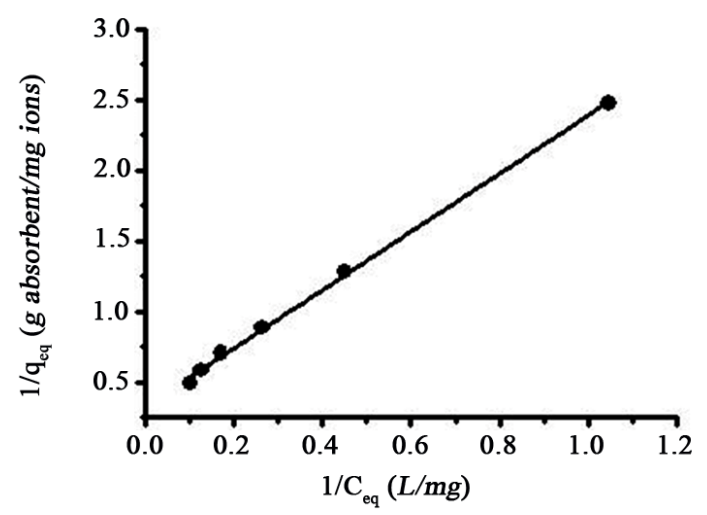

(b) Freundlich

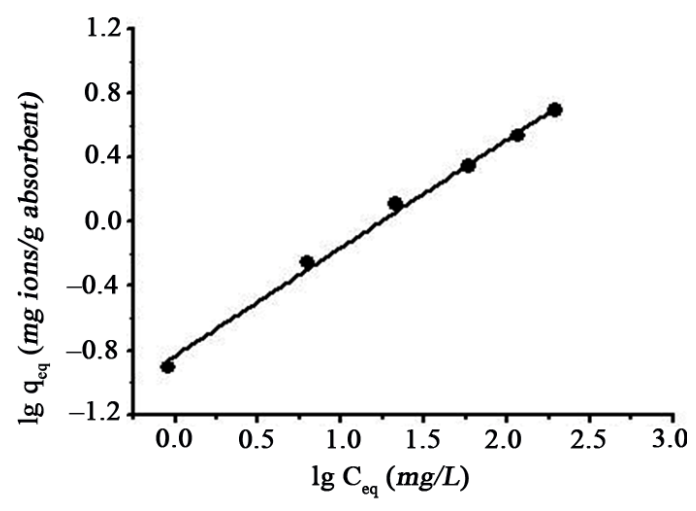

Figure 6. Effect of $\mathrm{pH}$ on adsorption of $\mathrm{Pb}(\mathrm{II})$ onto SB in a magnetic field (Metal concentration: $30 \mathrm{mg} / \mathrm{L}$; Dose: $0.0100 \mathrm{~g} / \mathrm{ml}$; Exposure time: $45 \mathrm{~min}$; Strength of magnetic field: $480 \mathrm{kA} / \mathrm{m})$.

Table 2. Parameters for the Langmuir and Freundlich equations.

\begin{tabular}{ccccccc}
\hline \multirow{2}{*}{ Metal ions } & \multicolumn{3}{c}{ Langmuir } & \multicolumn{3}{c}{ Freundlich } \\
\cline { 2 - 7 } & $\mathrm{Q}^{0}$ & $\mathrm{~b}$ & $\mathrm{R}^{2}$ & $\mathrm{~K}$ & $1 / \mathrm{n}$ & $\mathrm{R}^{2}$ \\
\hline $\mathrm{Pb}(\mathrm{II})$ & 3.2906 & $14.50 \times 10^{-2}$ & 0.9971 & 0.1519 & 0.6595 & 0.9960 \\
\hline
\end{tabular}

The values were the average of three experiments; the temperature was $298 \mathrm{~K}$.

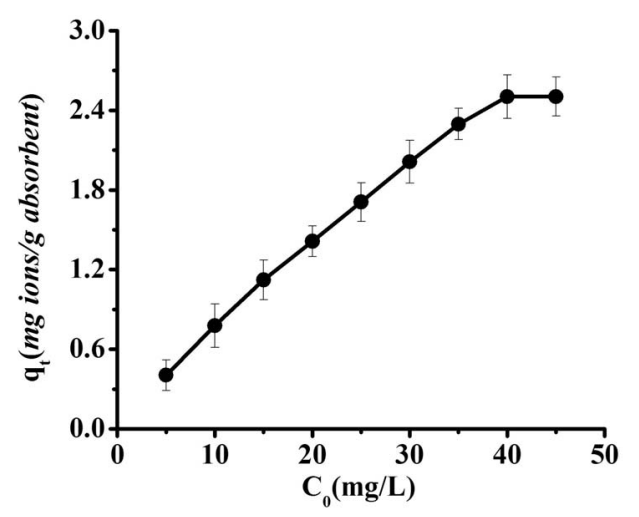

Figure 7. Effect of metal concentration on adsorption of $\mathrm{Pb}(\mathrm{II})$ onto SB in a magnetic field (Dose: $0.0100 \mathrm{~g} / \mathrm{ml}$; Exposure time: $45 \mathrm{~min}$; Strength of magnetic field: $480 \mathrm{kA} / \mathrm{m}$; pH 4).

\subsection{Discussion of the Mechanism for Magnetic Treatment of Adsorption Systems}

It was previously reported [36] that magnetic treatment could reduce the viscosity and surface tension of solutions, an effect possibly concerned with resonance. When the magnetic field and the oscillation frequency of the molecules were in tune, resonance could occur. This resonance would then impart energy to the system for activation, changing the structure and nature of the material in the magnetic field. Magnetic treatment could thus promote the adsorption of metal ions. However, the mechanism of magnetic treatment remains to be clarified in an in-depth study.

\section{Conclusions}

The adsorption of chitosan (CS) could be improved by condensation with benzaldehyde to form a Schiff base. The chitosan-benzaldehyde Schiff base (SB) had an excellent adsorption capacity for $\mathrm{Pb}(\mathrm{II})$. This $\mathrm{SB}$ could adsorb twice as much $\mathrm{Pb}$ (II) as CS in half the time. This adsorption could be expressed with the Langmuir and Freundlich isotherm equation.

The adsorption ability, including adsorption amount and adsorption rate, could be enhanced with a suitable magnetic field. For example, upon treatment with a field strength of $480 \mathrm{kA} / \mathrm{m}$, the adsorption equilibrium period for metal ions on $\mathrm{SB}$ shortened from $60 \mathrm{~min}$ to $30 \mathrm{~min}$. In the future, the mechanism of magnetic treatment on adsorption will have to be studied deeply.

\section{Acknowledgements}

The authors are thankful for financial support from the Doctoral Discipline Special Foundation of the Education Ministry of China (20050561014) and the National "863" Science \& Technology Project of China (2007AA100405).

\section{REFERENCES}

[1] T. L. Liao, G. L. Sun and H. P. Dong, "Research on the Toxicity of Lead Ion in Mimetic Membrane," Guangdong Chemical Industry, No. 1, 2010, pp. 53-55. http://202.116.64.102:81/asp/Detail.asp

[2] Z. Aksu, F. Gönen and Z. Demircan, "Biosorption of Chromium(VI) Ions by Mowital $\mathrm{B}_{3} \mathrm{OH}$ Resin Immobi- 
lized Activated Sludge in a Packed Bed: Comparison with Granular Activated Carbon," Process Biochemistry, Vol. 38, No. 2, 2002, pp. 175-186. doi:10.1016/S0032-9592(02) 00053-5

[3] R. S. Bai and E. Abraham, "Studies on Chromium (VI) Adsorption Desorption Using Immobilized Fungal Biomoss," Bioresource Technology, Vol. 87, No. 1, 2003, pp. 17-26. doi:10.1016/S0960-8524(02)00222-5

[4] B. Benguella and H. Benaissa, "Effects of Competing Cations on Cadmium Biosorption by Chitin," Colloids and Surfaces A: Physicochemical and Engineering Aspects, Vol. 201, No. 1-3, 2002, pp. 143-150. doi:10.1016/S0927- 7757(01)00899-8

[5] F. Veglio and F. Beolchini, "Removal of Met also by Biosorption: A Review," Hydrometallurgy, Vol. 44, No. 3, 1997, pp. 301-316. doi:10.1016/S0304-386X(96)00059-X

[6] K. Higashitani, A. Kage, S. Katamura, K. Imai and S. Hatade, "Effects of a Magnetic Field on the Formation of $\mathrm{CaCO}_{3}$ Particles," Journal of Colloid and Interface Science, Vol. 156, No. 1, 1993, pp. 90-95. doi:10.1006/ jcis.1993. 1085

[7] S. Kobe, G. Dražić, A. C. Cefalas, E. Sarantopoulou and J. Stražišar, "Nucleation and Crystallization of $\mathrm{CaCO}_{3}$ in Applied Magnetic Fields," Crystal Engineering, Vol. 5, No. 3-4, 2002, pp. 243-253. doi:10.1016/S1463-0184(02) 00035-7

[8] S. Kobe, G. Dražić, P. J. McGuiness, T. Meden, E. Sarantopoulou, Z. Kollia and A. C. Cefalas, "Control over Nanocrystalization in Turbulent Flow in the Presence of Magnetic Fields," Materials Science and Engineering, Vol. 23, No. 6-8, 2003, pp. 811-815. doi:10.1016/i.msec. 2003.09.136

[9] R. Gher, Z. A. Zhai, J. A. Finch and S. R. Rao, "Reduction of Soluble Mineral Concentrations in $\mathrm{CaSO}_{4}$ Saturated Water Using a Magnetic Field," Water Research, Vol. 29, No. 3, 1995, pp. 933-940. doi:10.1016/0043-1354(94) 002 14-R

[10] E. Chibowski, L. Hołysz and A. Szcześ, "Time Dependent Changes in Zeta Potential of Freshly Precipitated Calcium Carbonate," Colloids and Surfaces A: Physicochemical and Engineering Aspects, Vol. 222, No. 1-3, 2003, pp. 41-54. doi:10.1016/S0927-7757(03)00232-2

[11] L. Hołysz, E. Chibowski and A. Szcześ, "Influence of Impurity Ions and Magnetic Field on the Properties of Freshly Precipitated Calcium Carbonate," Water Research, Vol. 37, No. 14, 2003, pp. 3351-3360. doi:10.1016/S0043-1354 (03) 00159-3

[12] L. Hołysz, A. Szcześ and E. Chibowski, "Effects of a Static Magnetic Field on Water and Electrolyte Solutions," Journal of Colloid and Interface Science, Vol. 316, No. 2, 2007, pp. 996-1002. doi:10.1016/j.jcis.2007.08.026

[13] J. M. D. Coey and S. Cass, "Magnetic Water Treatment," Journal of Magnetism and Magnetic Materials, Vol. 209, No. 1-3, 2000, pp. 71-74. doi:10.1016/S0304-8853(99) 00648-4

[14] C. Gabrielli, R. Jaouhari, G. Maurin and M. Keddam, "Magnetic Water Treatment for Scale Prevention," Water
Research, Vol. 35, No. 13, 2001, pp. 3249-3259. doi:10. 1016/S0043-1354(01)00010-0

[15] E. Chibowski, A. Szcześ and L. Hołysz, "Influence of Sodium Dodecyl Sulfate and Static Magnetic Field on the Properties of Freshly Precipitated Calcium Carbonate," Langmuir, Vol. 21, No. 18, 2005, pp. 8114-8122.

[16] S. A. Parsons, B. L. Wang, S. J. Judd and T. Stephenson, "Magnetic Treatment of Calcium Carbonate Scale-Effect of pH Control," Water Research, Vol. 31, No. 2, 1997, pp. 339-342. doi:10.1016/S0043-1354(96)00238-2

[17] J. S. Backer and S. J. Judd, "Magnetic Amelioration of Scale Formation," Water Research, Vol. 30, No. 2, 1996, pp. 247-260. doi:10.1016/0043-1354(95)00184-0

[18] H. Al-Qahtani, "Effect of Magnetic Treatment on Gulf Seawater," Desalination, Vol. 107, No. 1, 1996, pp. 7581.

[19] F. Alimi, M. Tlili, C. Gabrielli, M. Georges and M. B. Amor, "Effect of a Magnetic Water Treatment on Homogeneous and Heterogeneous Precipitation of Calcium Carbonate," Water Research, Vol. 40, No. 10, 2006, pp. 1941-1950. doi:10.1016/j.watres.2006.03.013

[20] K. Higashitani, K. Okuhara and S. Hatade, "Effects of Magnetic Fields on Stability of Nonmagnetic Ultrafine Colloidal Particles," Journal of Colloid and Interface Science, Vol. 152, No. 1, 1992, pp. 125-131. doi:10.1016/ 0021-9797(92)90013-C

[21] K. Higashitani, H. Iseri, K. Okuhara, A. Kage and S. Hatade, "Magnetic Effects on Zeta Potential and Diffusivity of Nonmagnetic Colloidal Particles," Journal of Colloid and Interface Science, Vol. 172, No. 2, 1995, pp. 383-388. doi:10.1006/jcis.1995.1268

[22] J. Oshitani, R. Uehara and K. Higashitani, "Magnetic Effects on Electrolyte Solutions in Pulse and Alternating Fields," Journal of Colloid and Interface Science, Vol. 209, No. 2, 1999, pp. 374-379. doi: $10.1006 /$ jeis. 1998.5898

[23] P. Vallée, J. Lafait, L. Legrand, P. Mentré, M. O. Monod and Y. Thomas, "Effects of Pulsed Low Frequency Electromagnetic Fields on Water Characterized by Light Scattering Techniques: Role of Bubble," Langmuir, Vol. 21, No. 6, 2005, pp. 2293-2299. doi:10.1021/la047916u

[24] M. C. Amiri and A. A. Dadkhah, "On Reduction in the Surface Tension of Water Due to Magnetic Treatment," Colloids Surfaces A: Physicochemical and Engineering Aspects, Vol. 278, No. 1-3, 2006, pp. 252-255. doi:10.1016/j.colsurfa.2005.12.046

[25] H. Madsen, "Influence of Magnetic Field on the Precipitation of Some Inorganic Salts," Journal of Crystal Growth, Vol. 152, No. 1-2, 1995, pp. 94-100. doi:10.1016/0022-0248(95)00103-4

[26] M. Colic and D. Morse, "The Elusive Mechanism of the Magnetic 'Memory' of Water," Colloids and Surfaces A: Physicochemical and Engineering Aspects, Vol. 154, No. 1-2, 1999, pp. 167-174. doi:10.1016/S0927-7757(98)00894-2

[27] K. Higashitani and J. Oshitani, "Magnetic Effects on Thickness of Adsorbed Layer in Aqueous Solutions Evaluated Directly by Atomic Force Microscope," Jour- 
nal of Colloid and Interface Science, Vol. 204, No. 2, 1998, pp. 363-368. doi:10.1006/jcis. 1998.5590

[28] P. Wanvimol and C. Suwabun, "Conjugation of Gallic Acid onto Chitosan: An Approach for green and Water-Based Antioxidant," Carbohydrate Polymers, Vol. 72, No. 1, 2008, pp. 169-177.

doi:10.1016/j.carbpol.2007.08.002

[29] G. Ma, D.-Z. Yang, Y.-S. Z., X. Ming, J. F. Kennedy and N. Jun, "Preparation and Characterization of WaterSoluble N-Alkylated Chitosan," Carbohydrate Polymers, Vol. 74, No. 1, 2008, pp. 121-126. doi:10.1016/j.carbpol.2008.01.028

[30] C. Peggy, K. Motoichi, E. C. Joo, Y.-Y. Yang, "Synthesis and Characterization of Chitosan-G-Poly(Ethylene Glycol)-Folate as a Non-Viral Carrier for Tumor-Targeted Gene Delivery," Biomaterials, Vol. 28, No. 3, 2007, pp. 540-549. doi:10.1016/j.biomaterials.2006.08.046

[31] N. Zerrouk, G. Corti, S. Ancillotti, F. Maestrelli, M. Cirri and P. Mura, "Influence of Cyclodextrins and Chitosan, Separately or in Combination, on Glyburide Solubility and Permeability," European Journal of Pharmaceutics and Biopharmaceutics, Vol. 62, No. 3, 2006, pp. 241-246. doi:10.1016/j.ejpb.2005.08.010
[32] V. M. Ramos, N. M. Rodríguez, M. S. Rodríguez, A. Heras and E. Agulló, "Modified Chitosan Carrying Phosphonic and Alkyl Groups," Carbohydrate Polymers, Vol. 51, No. 4, 2003, pp. 425-429. doi:10.1016/S0144-8617(02)00211-4

[33] G. Manuel, S. N. Antonio, E. M. Maria, et al., "A Derivative of Chitosan and 2,4-Pentanedione with Strong Chelating Properties," Carbohydrate Research, Vol. 233, No. 2, 1992, pp. 255-259. doi:10.1016/S0008-6215(00)90939-X

[34] L.-H. Duan, J.-Q. Yang and S.-Y. Guo, "Study on Property of Modified Chitosan for Absorbing Cr (VI) in Magnetic Field," Journal of Shanxi University of Science and Technology, Vol. 28, No. 6, 2010, pp. 1-6.

[35] F. C. Wu, R. L. Tseng and R. S. Juang, "Comparative Adsorption of Metal and Dye on Flake- and Bead-Types of Chitosans Prepared from Fishery Wastes," Journal of Hazardous Materials, Vol. 73, No. 1, 2000, pp. 63-75. doi:10.1016/S0304-3894(99)00168-5

[36] B. S. Zheng, S. Y. Guo, L. Li, et al., "Studies on the Strengthening Evaporation of Solution by Magnetic Treatment," Journal of South China University Technology (Natural Science), Vol. 23, No. 7, 1995, pp. 20-25. 